\title{
An Economic Analysis of the Environmental Impact of PM2.5 Exposure on Health Status in Three Northwestern Mexican Cities
}

\section{Luis Armando Becerra-Pérez ( $\nabla$ becerra@uas.edu.mx )}

Autonomous University of Sinaloa: Universidad Autonoma de Sinaloa https://orcid.org/0000-00016919-0621

\section{Roberto A. Ramos-Álvarez}

Autonomous University of Sinaloa: Universidad Autonoma de Sinaloa

Juan J. DelaCruz

Lehman College of CUNY Division of Natural and Social Science

\section{Benjamín García-Páez}

UNAM Facultad de Economia: Universidad Nacional Autonoma de Mexico Facultad de Economia

\section{Federico Páez-Osuna}

Instituto de Ciencias del Mar y Limnología: Universidad Nacional Autonoma de Mexico Instituto de

Ciencias del Mar y Limnologia

\section{Guillermo Cedeño-Laurent}

Harvard University T H Chan School of Public Health

\section{Elena Boldo}

Carlos III Health Institute: Instituto de Salud Carlos III

\section{Research}

Keywords: Value of a statistical life, Human health, Avoidable mortality, Life expectancy, Air pollution

Posted Date: June 1st, 2021

DOI: https://doi.org/10.21203/rs.3.rs-559152/v1

License: (c) (i) This work is licensed under a Creative Commons Attribution 4.0 International License. Read Full License 


\section{An Economic Analysis of the Environmental Impact of $\mathbf{P M}_{2.5}$ Exposure on}

\section{Health Status in Three Northwestern Mexican Cities}

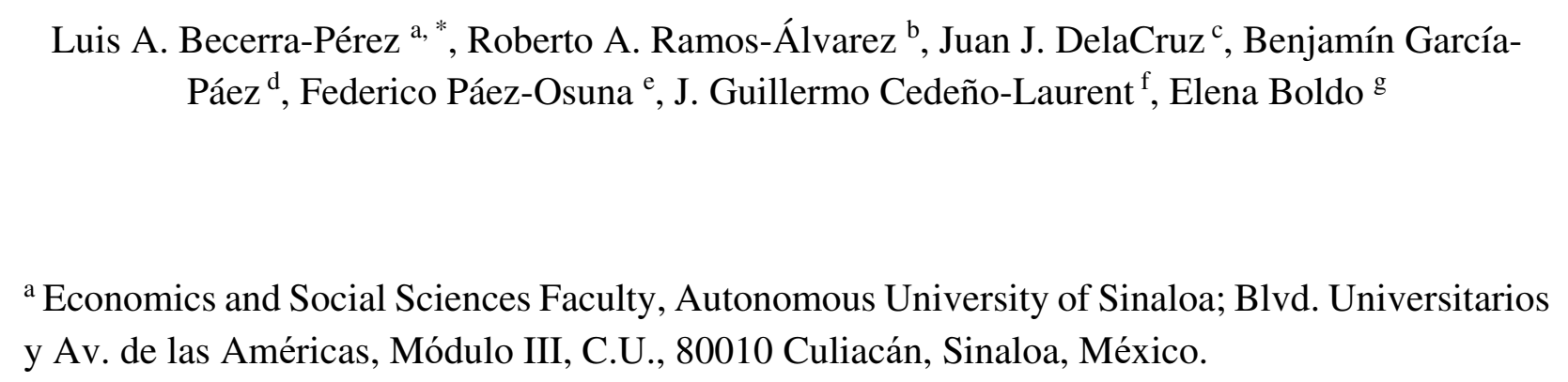

${ }^{\mathrm{b}}$ Program in Social Sciences, Autonomous University of Sinaloa; Blvd. Universitarios y Av. de las Américas, Módulo III, C.U., 80010 Culiacán, Sinaloa, México.

${ }^{\mathrm{c}}$ Lehman College, The City University of New York; 250 Bedford Park Boulevard West, Bronx, NY 10468, USA.

${ }^{\mathrm{d}}$ Faculty of Economy, Division of Postgraduate Studies, National Autonomous University of Mexico; Interior s/n Ciudad Universitaria, Coyoacán, 04510 CDMX, México.

e Institute of Sciences of the Sea and Limnology, National Autonomous University of Mexico; Cap. Joel Montes Camarena s/n, Cerro del Vigía 82000, Mazatlán, Sinaloa, México.

${ }^{\mathrm{f}}$ Harvard T.H. Chan School of Public Health, Harvard University; 677 Huntington Ave, Boston, MA 02115, USA.

g Consortium for Biomedical Research in Epidemiology and Public Health (CIBERESP), Carlos III Institute of Health and, Environmental Health Department, Madrid City Council, Madrid, Spain. Avenida Mediterráneo 62, planta 1ra 28007, Madrid, España.

*Corresponding author: becerra@uas.edu.mx 


\section{Abstract}

37 Background: This study provides an assessment of the health effects due to exposure to 38 particulate matter $\mathrm{PM}_{2.5}$ (diameter $<2.5 \mu \mathrm{m}$ that cause the air to appear hazy when levels are

39 elevated) in three medium size cities of north western Mexico (Los Mochis, Culiacan and

40 Mazatlan). We computed the total avoidable premature mortality, avoidable cardiovascular

41 disease, gains in life expectancy, as well as the economic costs by air contamination corresponding

42 to $\mathrm{PM}_{2.5}$. To achieve this goal, the Health Impacts Assessment (HIA) methodology provided by

43 the European Aphekom Project was used. People in these cities are exposed to high $\mathrm{PM}_{2.5}$

44 concentrations that exceed limits implemented in domestic and international guidelines.

45 Results: We determined the cost of the $\mathrm{PM}_{2.5}$ pollutant associated with health outcomes under two

46 different scenarios: Official Mexican Standard (NOM, Spanish acronym) and World Health

47 Organization (WHO). The mean $\mathrm{PM}_{2.5}$ concentrations in 2017 were $22.8,22.4$ y $14.1 \mu \mathrm{g} / \mathrm{m}^{3}$ for

48 the cities Los Mochis, Mazatlan and Culiacan, respectively. The mean avoidable mortality for all

49 causes associated to the exposure to $\mathrm{PM}_{2.5}$ in the three cities was 638 for the NOM scenario (i.e.,

50 with a reduction to $12 \mu \mathrm{g} / \mathrm{m}^{3}$ ) compared to 739 for the WHO scenario (reduction to $10 \mu \mathrm{g} / \mathrm{m}^{3}$ ).

51 Complying with the WHO guideline of $10 \mu \mathrm{g} / \mathrm{m}^{3}$ in annual PM2.5 mean would add up to 15 months

52 of life expectancy at age 30 , depending on the city.

53 Conclusions: The mean economic cost per year of the $\mathrm{PM}_{2.5}$ effects on human life in these three

54 cities was $\$ 600$ (NOM scenario) and \$695 million dollars (WHO scenario). Effective public health

55 and industrial policy interventions are socially advantageous and cost-saving to promote better 56 health.

57 Keywords: Value of a statistical life, Human health, Avoidable mortality, Life expectancy, Air 58 pollution 


\section{Background}

60 Air pollution caused by industrialization and population growth is a major public health issue

61 worldwide. Empirical evidence shows that current levels of air pollution in major urban areas place

62 a considerable risk for human health [5]. The Global Burden of Disease Study [23] estimates that

637.2 million premature deaths in 2017 were due to environmental factors, of which 3.4 million were

64 due to ambient fine particulate matter $\left(\mathrm{PM}_{2.5}\right)$ and ozone pollution [44]. This particulate matter is

65 an air pollutant that is negatively associated with people's health when is highly concentrated in

66 air. According to the Institute for Health Metrics and Evaluation [33], air pollution is the fourth

67 leading cause of mortality worldwide, and the $\mathrm{PM}_{2.5}$ is one of the most harmful pollutants. The

$68 \mathrm{PM}_{2.5}$ are either solid or liquid microparticulate suspended in the air with an aerodynamic diameter

69 of at most 2.5 micrometers $(\mu \mathrm{m})$, which is equivalent to one thousandth of a millimeter [13, 15 ,

$7032,34,58,67]$. Health Impact Assessments (HIA) methods are often used in environmental

71 studies. HIA comprises a combination of procedures by which a policy or program is evaluated as

72 to its potential effects on people's health and the distribution of those effects within the population

$73[20]$.

74 Studies of environmental pollution in North America [63] and in Europe [8] reveal that chronic

75 exposure to $\mathrm{PM}_{2.5}$ is associated with increased mortality in the long run. The World Health

76 Organization [68] estimates that around 7 million people die from exposure to breathing particulate

77 matter every year. These fine particulate travels through the airways into the lungs, stay in the

78 alveoli and affect the cardiovascular system, causing cerebrovascular events, heart diseases, lung

79 cancer, chronic obstructive lung disease and respiratory infections $[1,17,22,48,68,70]$.

80 Furthermore, empirical evidence shows the links between cardiometabolic and mental diseases to

81 related to specific levels of $\mathrm{PM}_{2.5}$ in cities with high human concentration and industrial activity. 
82 The current literature has documented the positive relationship between $\mathrm{PM}_{2.5}$ and a wide range of

83 diseases such as stroke [72]; Alzheimer and dementia [61]; asthma [4]; atopic dermatitis and

84 rhinitis [28]; low birth weight [62]; breast cancer [73]; melanogenesis [54]; chronic obstructive

85 pulmonary disease [27]; autism spectrum disorders [12]; depression [21]; sleep loss [31];

86 aggressive behavior [9]; type 2 diabetes [71]; Parkinson [26] and chronic kidney disease [69].

87 Premature mortality attributable to air pollution around the world increased $32 \%$ from 2.2 million

88 deaths per year in 1990 to 2.9 million deaths in 2013 [33]. Premature mortality is adjusted

89 according to regions, countries and is contingent on emission levels, urban concentration,

90 meteorological conditions (winds, sun, height, heat or relative humidity), government policies on

91 the environment and other factors. Based on World Bank (WB) and Institute for Health Metrics

92 and Evaluation (IHME) [33] estimations, air pollution and exposure to $\mathrm{PM}_{2.5}$ caused around 48

93 premature deaths per 100,000 inhabitants worldwide with Norway, Australia and Ireland being the

94 countries achieving the highest reduction of air pollution. Conversely, Afghanistan, Turkmenistan

95 and Yemen were the countries with the highest risk of dying from $\mathrm{PM}_{2.5}$ exposures. The economic

96 cost of the air pollution worldwide was estimated to be around \$5.1 trillion US dollars (USD) in

972013 [33]. During the same year, environmental degradation caused by poor air quality in Mexico

98 was associated to 26,484 deaths with estimated losses of $\$ 37.7$ billion USD, which is equivalent

99 to $1.9 \%$ reduction in the Mexican Gross Domestic Product (GDP) [33]. Elevated pollution levels

100 experienced in several Mexican regions require strong and clear policy actions to improve air

101 quality and population's health, thus policy makers should aim to reduce PM2.5 emissions below

102 the Mexican Official Standard NOM-025-SSA1-2014 [50] of $12 \mu \mathrm{g} / \mathrm{m}^{3}$ or the WHO [66] air

103 quality guideline $\left(10 \mu \mathrm{g} / \mathrm{m}^{3}\right)$. The National Institute of Statistics and Geography (INEGI, Spanish 
104 acronym) reported investments to combat environmental pollution equivalent to $2.8 \%$ of the 105 Mexican GDP in 2017, the highest share directed to public health in a single year [41].

106 The National Institute of Ecology and Climate Change (INECC, Spanish acronym) [35] reported 107 environmental statistics for the three largest urban concentrations of Mexico. In 2014, 753 108 premature deaths of people 30 years of age and older could be prevented in the Mexico City and 109 its metropolitan area if the minimum pollution levels required by law were observed with an 110 economic cost estimated in $\$ 1.3$ billion USD according to the NOM [50]. Likewise, under the 111 WHO environmental standards [66], the number of avoidable premature deaths were estimated at 1121,421 with an economic cost of \$2.4 billion USD. For Guadalajara, this report [35] estimated 301 113 avoidable deaths with an economic impact of \$475 million USD (of 2010) under the Mexican 114 standard [50] and 394 avoidable deaths with a cost of \$634 million USD (of 2010) under the WHO 115 guideline [66]. For Monterrey, the number of avoidable deaths were 263 under the Mexican 116 standard with a cost of \$396 million USD and the number of avoidable deaths were 355 with an 117 economic impact of \$554 million USD of 2010, respectively [35]. Moreover, the central region of 118 Mexico showed a mean yearly $\mathrm{PM}_{2.5}$ concentrations of $24.6 \mu \mathrm{g} / \mathrm{m}^{3}$ during 2017, affecting areas 119 such as Mexico City, Toluca, Puebla, Hidalgo, Queretaro, Morelos and Tlaxcala. These places 120 experienced twice the normal levels of permissible pollution according to the Mexican standard 121 [50] and 2.5 higher using the WHO guideline as reference [66]. Under these levels of air pollution, 122 an estimated number of 8,464 and 9,767 could have been avoided with economic benefit estimated 123 as $\$ 8.8$ billion USD and $\$ 10.1$ billion dollars considering the Mexican standard and WHO metrics, 124 respectively [36].

125 Trejo-Gonzalez et al. [60] implemented a HIA in 15 Mexican cities (Mexico City, Toluca, 126 Guadalajara, Guanajuato, Monterrey, Queretaro, Puebla, Tlaxcala, Tepic, Merida, Leon, Silao, 
127 Irapuato, Salamanca and Celaya), showing that the mean concentration of $\mathrm{PM}_{2.5}$ per year ranged

128 between $9.4 \mu \mathrm{g} / \mathrm{m}^{3}$ and $32.3 \mu \mathrm{g} / \mathrm{m}^{3}$, being the lowest concentration in Tepic and the highest in

129 Toluca. Under hypothetical scenarios, decreasing $\mathrm{PM}_{2.5}$ concentration levels to $12 \mu \mathrm{g} / \mathrm{m}^{3}$ y 10

$130 \mu \mathrm{g} / \mathrm{m}^{3}$ would have avoided 12,722 and 14,666 deaths with an estimated economic cost of \$20.9

131 and \$24.1 billion USD respectively. A significant site of environmental pollution is located around

132 the thermal power plant in Tuxpan (State of Veracruz); this plant has produced dangerous levels

133 of pollution caused by the emission of $\mathrm{PM}_{2.5}$ since it was built in 1991. Pollution emission in this

134 thermoelectrical facility is associated with more than 30 deaths per year and a social cost of $\$ 9$

135 million USD [74]. The $\mathrm{PM}_{2.5}$ is also associated with labor productivity problems that cause

136 economic losses when this pollutant exceeds the permissible limits. From this perspective,

137 Becerra-Pérez et al. [6] found for three cities in northwestern Mexico (Culiacan, Mazatlan, and

138 Los Mochis) a total of 261 (NOM) and 354 (WHO) preventable deaths occur as result of the

139 exposure to high levels of air pollution, estimating an economic cost of \$ 24 million and \$ 34

140 million for 2017, respectively.

141 The study uses the HIA framework to quantify the environmental effect on health outcomes and

142 the economic costs of $\mathrm{PM}_{2.5}$ exposure in Culiacan, Los Mochis and Mazatlan, cities located in the

143 northwestern State of Sinaloa, Mexico. We hypothesize that the proper implementation of the

144 current environmental policy is crucial to avoid premature mortality due to air pollution and $\mathrm{PM}_{2.5}$

145 emissions. The endpoints of this study are the number of avoidable deaths and the economic cost

146 of air pollution, using both the Official Mexican Standard (NOM-025-SSA1-2014) [50] and the

147 WHO guideline [66]. This research is significant because there is an absence of HIA evidence at

148 the local level regarding particulate matter, health status and human populations. Environmental 
149 problems are highly prevalent in large urban settlements and medium size cities with similar and

150 even worst air pollution issues.

151

\section{Methods}

\section{Study cities and data}

154 The three cities considered in this study are located in the state of Sinaloa, Mexico: Culiacan

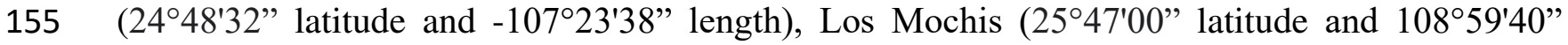
156 length), and Mazatlan (23 $12^{\prime} 01^{\prime \prime}$ latitude and $-106^{\circ} 25^{\prime} 20^{\prime \prime}$ length) [40]. These three urban

157 concentrations (Figure 1) account for 63\% of the state population, being Culiacan the largest city 158 with a population $\sim 1$ million inhabitants (32\% of the total state) and population density of 143.6 159 inhabitants per $\mathrm{km}^{2}$. Los Mochis and Mazatlan have populations of less than 500,000 each (31\% 160 of the total state) with population densities of 112.4 and 198.5 inhabitants per $\mathrm{km}^{2}$ [37, 38, 42].

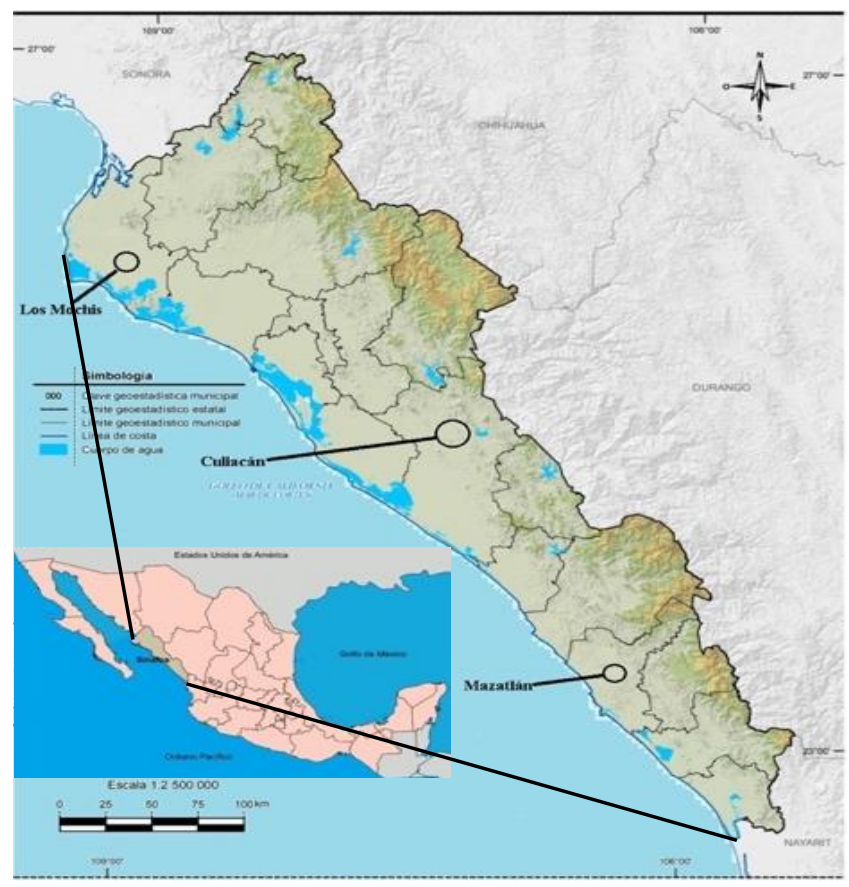

162 Fig. 1. Location of the three cities examined: Culiacan, Los Mochis and Mazatlan [38] 
163 Atmospheric emissions records were obtained from the State of Sinaloa's environmental

164 monitoring system, which has a fixed station in each of the selected cities measuring air quality 165 and in particular $\mathrm{PM}_{2.5}$. To measure these $\mathrm{PM}_{2.5}$, this monitoring system uses the Tapered Element 166 Oscillating Microbalances technology (TEOM), which is a widely used method to collect data on $167 \mathrm{PM}_{2.5}$ in real time. The valid average concentration per year of $\mathrm{PM}_{2.5}$ in 2017 were selected as the 168 exposure values, which were computed based on the daily concentration (hour/day) in the stations. 169 These values align with the Mexican standard (NOM-025-SSA1-2014) regarding the number of 170 observations stating that no more than $25 \%$ of the daily measurements should be missed to be 171 acceptable [50]. Demographic and health data of 2017 were obtained from official sources; the

172 INEGI [39] registered mortality based on the main cause of death among residents in our area of 173 study, providing the monthly number of deaths of people 30 years and older. Our HIA only 174 included health and demographic information of people 30 years and older in the three cities of 175 our sample. In all cases, we applied the criteria of the International Classification of Diseases (ICD176 10), selecting code A00-R99 to classify total mortality (external included) and code I00-I99 to 177 classify cardiovascular diseases only. Additionally, population data was retrieved from the 2010 178 National Population and Housing Census and updated to 2017 using the population growth rates 179 estimates by the Mexico’s National Council for Population [14].

180 The Concentration-Response Function (CRF)

181 The relationship between the concentration of air pollutants with total mortality and cardiovascular 182 diseases helps quantify public health risks. Our sample of cities were chosen on the basis of CRF's 183 data availability according to the American Cancer Society (ACS) [56], the largest research 184 assessing the effects of air pollution on human health. Our CRF's metrics are based on the long185 run average $\mathrm{PM}_{2.5}$ concentrations recorded from these sites. We also used the Harvard Six Cities 
186 cohort re-analysis [46] as well as the ACS follow up and space analysis, which relates

187 environmental pollution by particulate matter to mortality rates [45]. These studies provide reliable

188 estimation of uncertainty and decrease the variability among the exposed populations regarding

189 individual susceptibility, $\mathrm{PM}_{2.5}$ composition, minimum and maximum pollution concentrations

190 and exposition frequency. Pope et al. [56.57] also estimated an average relative risk (RR) of

191 general mortality of 1.06 [95\% CI: 1.02-1.11] and a RR for cardiovascular disease equal to 1.12

192 with a [95\% CI: 1.08-1.15]. A confidence interval (CI) describes the variability between the

193 measure obtained in a study and the actual measure of the population (the true value) as well as

194 indicates that within the given range is the real value of a parameter with $95 \%$ certainty [24, 49,

$19564]$.

196 Although the HIA methodology has been standardized in international studies, several local

197 decisions regarding data points and risk factors need to be taken into account during the estimation

198 of avoidable deaths. An important variable for this analysis is the CRF coefficient ( $\beta$ value) which

199 directly influences the measurement of the impact of pollutant exposure on population given

200 changes in the concentration level. This basic relationship can be expressed as follows [3]:

201

$$
\Delta y=y_{0}-e^{-\Delta x \beta}
$$

202 Where $\square \mathrm{y}$ represents the change in avoidable premature deaths in the health result associated with 203 the decrease in pollution concentrations at the baseline; yo is the base health outcome (deaths 204 according to ICD-10); e is the Napier constant; $\square \mathrm{x}$ is the change of pollution concentrations in a 205 given scenario; $\square$ is the concentration-response function (CRF) coefficient, which is calculated 206 according to:

207

$$
\mathrm{CRF}=\frac{\ln (\mathrm{RR})}{\Delta \mathrm{C}}
$$


208 Where CRF is the concentration-response function; ln (RR) is the natural logarithm of the relative

209 risk (RR), which was selected from previous epidemiological studies to estimate the long-term

210 effects of $\mathrm{PM}_{2.5}$ on overall and cardiovascular mortalities; $\square \mathrm{C}$ captures deviations in pollution

211 concentration from $10 \mu \mathrm{g} / \mathrm{m}^{3}[56,57]$. The $\square$ value was computed when variables in equation (2),

212 representing the relationship between changes in the particulate matter concentration and changes

213 in the impact on the exposed population.

\section{Tool used: Aphekom}

215 HIA is a robust methodology designed to quantify the impact of air pollution on human health as

216 a result of air pollution by particulate matters. HIA uses different platforms and among them the

217 one developed by the European Aphekom Project, which describes specific equations to estimate

218 life expectancy and avoidable early deaths [2]. Aphekom is a European project developed to

219 improve knowledge and communication for decision-making on air pollution and health in Europe

220 [3]. This tool is based on MS Excel and has been widely used in several long run studies for

221 European cities and provided seminal findings that served as the baseline in the design of

222 environmental policies aiming to ameliorate the effects of $\mathrm{PM}_{2.5}$ pollution (e.g. 10, 11, 29, 30, 47,

223 55]. Aphekom simulates outputs on how the number of deaths per 100,000 inhabitants would

224 decrease if $\mathrm{PM}_{2.5}$ declined under specific predetermined values. This platform also computes the 225 average gains in life expectancy of those exposed to air pollution.

226 We used Aphekom as a tool to analyze the impact of pollution on health under two scenarios: (i)

227 scenario NOM, which imply the reduction in the $\mathrm{PM}_{2.5}$ average concentration value per year down

228 to12 $\mu \mathrm{g} / \mathrm{m}^{3}$ in each of the selected cities. Furthermore, Aphekom requires the classification of the

229 population into categories to estimate gains in life expectancy, thus standardized mortality rates

230 were computed for each 5 years of age. This simulation responds to the assumptions of the 
231 Mexican normativity NOM-025-SSA1-2014, which establish $12 \mu \mathrm{g} / \mathrm{m}^{3}$ to be the maximum

232 allowed level of air pollution [50]; and (ii) scenario WHO, which imply the reduction in the $\mathrm{PM}_{2.5}$

233 average concentration value per year down to $10 \mu \mathrm{g} / \mathrm{m}^{3}$ in each of the appraised cities. This scenario

234 abides to the WHO international benchmarks that requires emission below to $10 \mu \mathrm{g} / \mathrm{m}^{3}[66]$.

235 The model restrictions were set at $\mathrm{PM}_{2.5}<12 \mu \mathrm{g} / \mathrm{m}^{3}$ for the $\mathrm{NOM}$ and $\mathrm{PM}_{2.5}<10 \mu \mathrm{g} / \mathrm{m}^{3}$ in the

236 WHO simulation. In both cases, the reduction in pollution concentration is equal to zero, assuming

237 that total current deaths would not be attributed to the abovementioned pollutant. Furthermore, we

238 used the same $\square$ value in all age groups in which the population was classified. Aphekom shows

239 the results as the "number of proposed premature deaths", understood as avoidable and "years of

240 life lost" understood as gains in life expectancy (see Appendix A).

241 Mexico's value of a statistical life (VSL)

242 Our economic evaluation requires a method capable to quantify the money value of total avoidable

243 deaths and other effects derived from exposure to poor air quality due to high levels of pollutants.

244 There are different types of methodologies aiming to estimate the value of life, cost of disability

245 and losses in productivity caused by air pollution. Independently of the approach, we multiplied

246 the Value of a Statistical Life (VSL) by the number of avoidable deaths. In our study, the VSL was

247 required to better understand the money cost of the number of deaths by total and cardiovascular

248 mortality. The VSL estimator compares, under a common unit of value, the cost and the benefits

249 of introducing public policy aiming to reduce mortality rates due to air pollution [18]. Although

250 VSL is debatable for ascribing money value to human life, this approach quantifies life for

251 statistical and resource allocation purposes, allowing to explain the cost of death. The VSL index

252 has been extensively applied in several economic studies to assess the cost of events. The

253 Organization for Economic Co-operation and Development (OECD) [51] provides a useful 
254 framework to estimate the VSL for Mexico, which was applied to the estimated avoidable deaths

255 in our sample of three cities. To compute these values, we used the following formula:

$256 V$ VSL Mexico $=$ VSLOECD $*\left(\frac{\text { PIBpMexico }}{\text { PIBpOECD }}\right)^{\mathrm{e}}$

257 Where VSL México is the Mexico's VSL in USD; VSLOECD is the OECD's VSL in USD;

258 PIBpMexico is the Mexico's GDP per capita in 2017; PIBpOECD is the OECD's GDP per capita

259 in 2017; and $e$ is for income elasticity. Hammit et al. [25] suggested values $>1$ for income elasticity

260 (e) aiming to estimate VSL in developing countries based on VSL of developed countries. We

261 used $\mathrm{e}=1.5$ because this is the elasticity value that better expresses social and economic conditions

262 of Mexico with respect to the rest of the OECD countries. All values were normalized and inflated

263 to 2017 using inflationary indexes and were compared with other existing estimations globally.

264 GDP information was retrieved from the World Bank data base [65].

265

266 Results

267 Avoidable deaths and life expectancy

268 The analyzed population was stratified by age groups of five years in each class. We accounted

269 for people 30 years and older exposed to air pollution cause by $\mathrm{PM}_{2.5}$ during 2017 in a sample of

270 three cities. Table 1 depicts the results per city and the total of the sample in which we can observe

271 that as we move along of the stratified age groups, the number of people potentially affected by

272 air pollution decreases, which is explained by the natural tendency of biological age of the

273 population. The median age in the state of Sinaloa is 29 years and although the state is mainly

274 made out of young people, the effects of $\mathrm{PM}_{2.5}$ on older populations can be noticeable. As the

275 person ages, the risk associated to pollution exposure increases due to the presence of multiple 
276 comorbidities, loss of mental abilities and the deterioration of physical functioning. Older adults

277 become the most susceptible to exposure to pollution as they age.

278

279

280

Table 1 Total population in the study cities over 30 years old in 2017

\begin{tabular}{lllllllllllll}
\hline City & $30-34$ & $35-39$ & $40-44$ & $45-49$ & $50-54$ & $\begin{array}{l}55- \\
59\end{array}$ & $\begin{array}{l}60- \\
64\end{array}$ & $\begin{array}{l}65- \\
69\end{array}$ & $\begin{array}{l}70- \\
74\end{array}$ & $\begin{array}{l}75- \\
79\end{array}$ & $84-$ & $85+$ \\
\hline Culiacan & 68,995 & 65,734 & 64,240 & 51,435 & 47,383 & 35,481 & 28,357 & 19,886 & 15,003 & 10,199 & 7,522 & 3,168 \\
Los & 30,199 & 34,642 & 34,146 & 29,504 & 24,159 & 17,865 & 14,811 & 11,730 & 9,143 & 6,200 & 4,050 & 2,061 \\
Mochis & & & & & & & & & & & \\
Mazatlan & 37,353 & 35,686 & 35,351 & 32,380 & 28,990 & 24,235 & 18,727 & 12,634 & 10,133 & 7,524 & 3,015 & 2,341 \\
Total & 136,547 & 136,062 & 133,737 & 113,319 & 100,532 & 77,581 & 61,895 & 44,250 & 34,279 & 23,923 & 14,587 & 7,570 \\
\hline
\end{tabular}

281

282

283

284

285

$$
\text { these targets by } 10.4 \text { and } 12.4 \text {, as well as Culiacan by } 2.1 \text { and } 4.1 \mu \mathrm{g} / \mathrm{m}^{3} \text {, correspondingly. }
$$




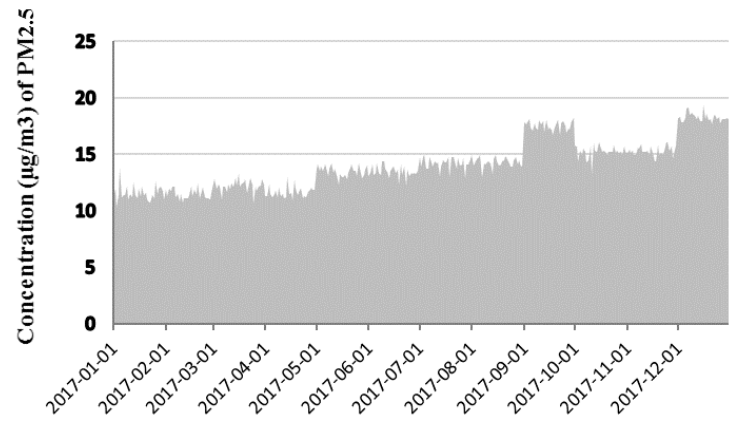

(b)

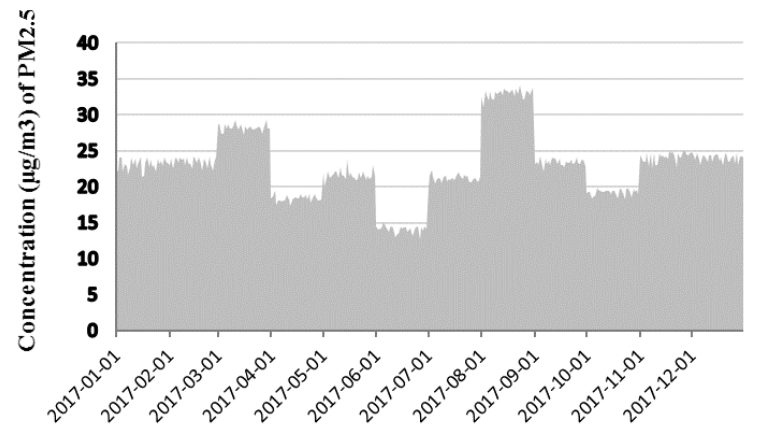

302

303

(c)

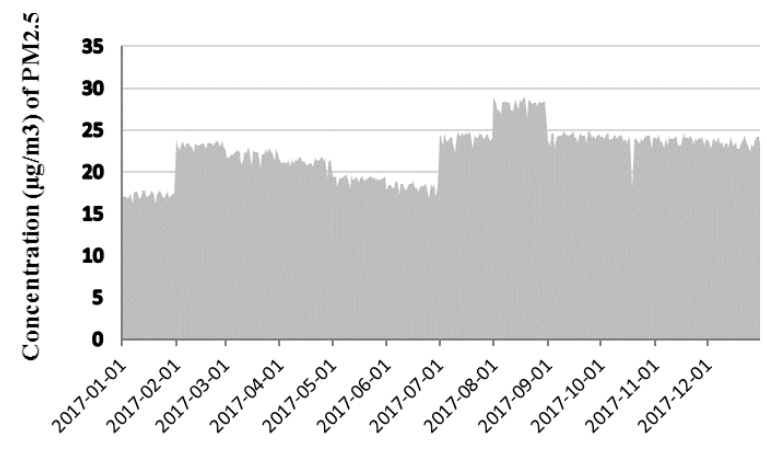

Fig. 2. $\mathrm{PM}_{2.5}$ Daily average concentrations $\left(\mu \mathrm{g} / \mathrm{m}^{3}\right)$ in cities participating in 
310 Figure 3 depicts the HIA results showing that the total avoidable mortality rate under the NOM for

311 Los Mochis was 104 cases per $10^{5}$ inhabitants, 102 cases for Mazatlan and 38 cases for Culiacan.

312 Also, under the NOM, avoidable cardiovascular mortality was estimated by 61 cases for Los

313 Mochis, 51 cases for Mazatlan and 20 cases per $10^{5}$ inhabitants for Culiacan. Under the WHO

314 scenario, the total avoidable mortality rate for Los Mochis was 115 events per $10^{5}$ inhabitants, 113

315 events for Mazatlan and 50 events for Culiacan. Likewise, under the WHO, avoidable

316 cardiovascular mortality was estimated by 67 events for Los Mochis, 57 events for Mazatlan and

31727 events per $10^{5}$ inhabitants for Culiacan.

318

319

320

321

322

323

324

325

326

327

328

329

330

331

332 
Impacts of PM2.5

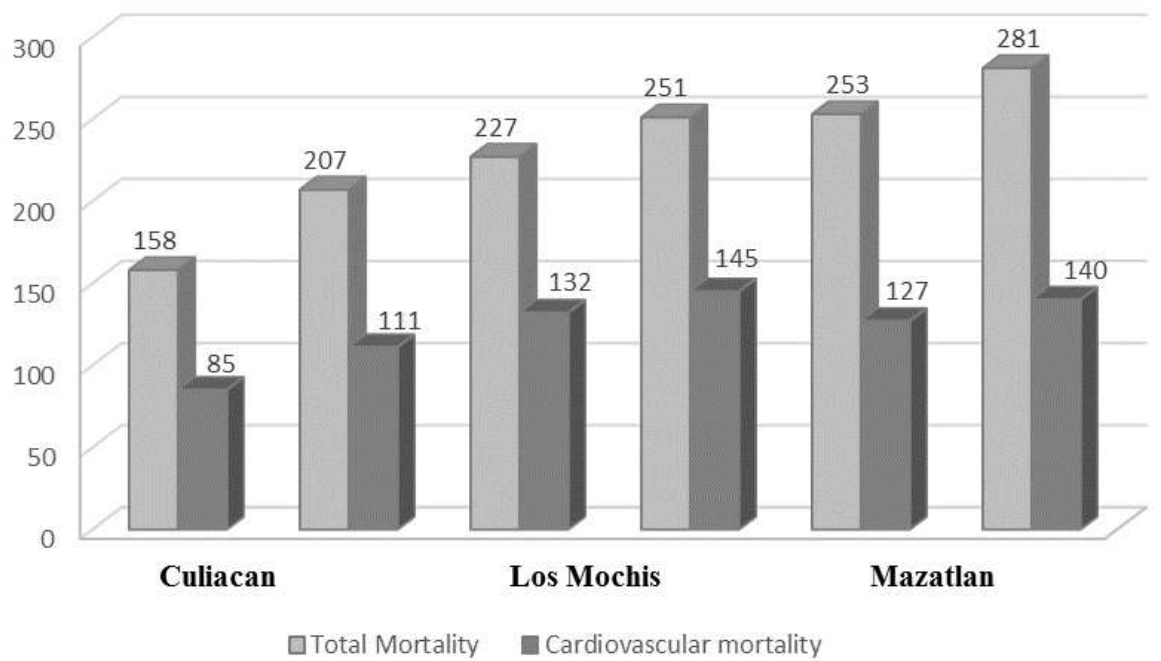

(b)

\section{Impacts of PM2.5}

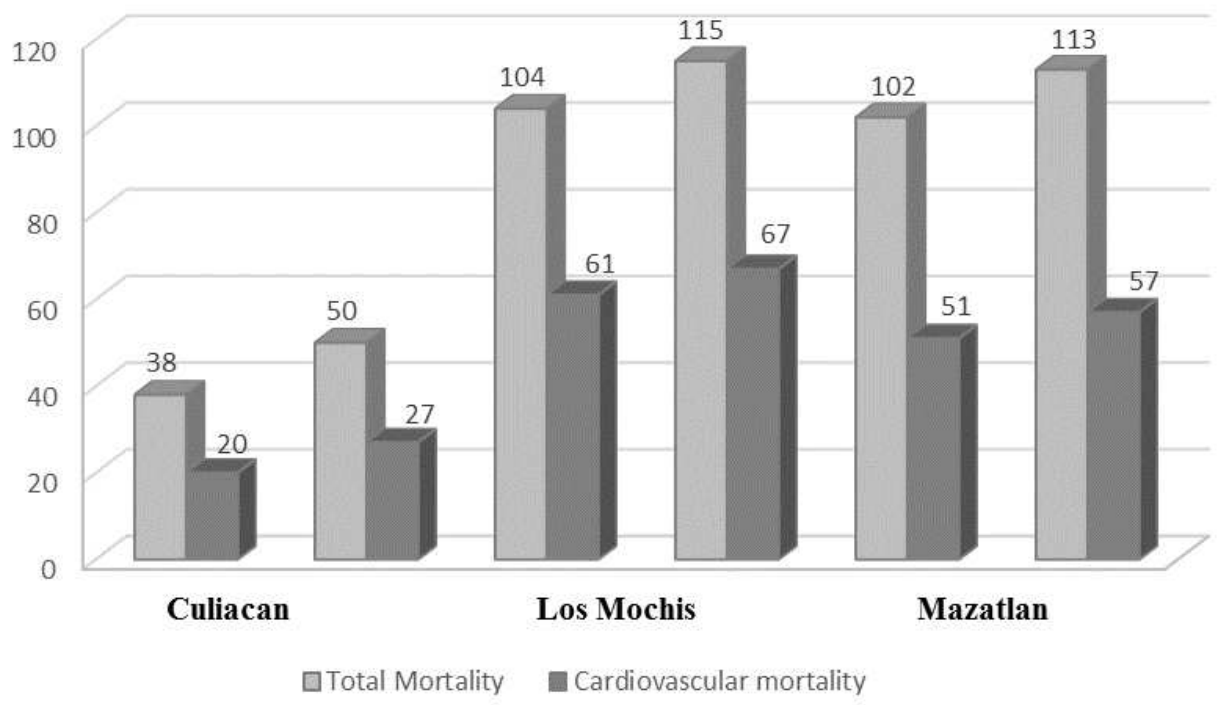

Fig. 3. Avoidable total and cardiovascular mortality due to the reduction in $\mathrm{PM}_{2.5}$ concentration levels (a) (cases per 100,000 inhabitants) (b), for population older than 30 years in the three cities 344 examined 
346 These findings support the idea that life expectancy would increase with a reduction in the $\mathrm{PM}_{2.5}$

347 average concentration per year below the national [50] and international [66] recommended

348 guidelines. Using the NOM measures, we sustain that mean increases in the life expectancy would

349 be 13 months for Los Mochis and Mazatlan, and 5 months for Culiacan. Under the WHO scenario,

350 mean increases in the life expectancy would be 15 months for Los Mochis and Mazatlan, and 7

351 months for Culiacan. These results are consistent with the estimated rate of avoidable deaths per

352 city because higher reductions in $\mathrm{PM}_{2.5}$ concentrations are expected to yield greater gains of life

353 expectancy.

354 Premature avoidable deaths associated with PM2.5 occurring among people 30 years and older were

355 estimated per each city of our sample showing the minimum, mean and maximum. We measured

356 three variables per location to include total deaths, cardiovascular deaths and gains in life

357 expectancy. According to the NOM simulation, in Culiacan the total avoidable mortality ranged

358 from 105 to $212($ mean $=158)$ people and cardiovascular death from 57 to $113($ mean $=85)$ people.

359 In Los Mochis, total avoidable death fluctuated from 154 to 303 (mean = 227) people and

360 cardiovascular death fluctuated between 88 and 176 (mean $=132$ ) people, while in Mazatlan

361 avoidable death oscillated between 169 and 337 (mean $=253$ ) people and the range for

362 cardiovascular deaths was 85 to 167 (mean =127) people. These results indicate that total number

363 of avoidable deaths in the three cities for all causes were 638, avoidable cardiovascular deaths

364 were 344 and gains in life expectancy would be 12 months, being Los Mochis and Mazatlan the

365 cities with the largest gains (Table 2).

366 Table 2 also shows result for the WHO scenario. In Culiacan, the total avoidable mortality ranged

367138 and 276 (mean = 207) people and the number of deceased for cardiovascular illnesses

368 fluctuated between 74 and 148 (mean =111) people. Under these same variables, Los Mochis had 
369167 to $335($ mean $=251)$ avoidable deaths and 97 to $193($ mean $=145)$ cardiovascular deaths.

370 Mazatlan could have avoided between 187 to $375($ mean $=281)$ and 94 to $189($ mean $=140)$

371 cardiovascular deaths. Considering average estimations only, the total number of avoidable deaths

372 in the three cities were 396 with potential gains in life expectancy of 15 months, having the largest

373 gains in Los Mochis and Mazatlan. According these average values and aggregating the data for

374 the three cities, the total avoidable fatalities associated to high levels of $\mathrm{PM}_{2.5}$ for 2017 in Sinaloa

375 were estimated as 638 and 739, depending on the metric (NOM or WHO) considered.

376

377

378

379

380

381

382

383

384

385

386

387

388

389

390

391

392 
Table 2 Avoidable total and cardiovascular mortality due to the reduction in $\mathrm{PM}_{2.5}$ concentration levels (total cases), and increase in gain in life expectancy for population older than 30 years

395

\begin{tabular}{lcccccc}
\hline \multirow{2}{*}{ Cities } & \multicolumn{3}{c}{ Scenario NOM } & \multicolumn{3}{c}{ Scenario WHO } \\
& Min. & Mean & Max. & Min. & Mean & Max. \\
\hline \multicolumn{5}{c}{ Total mortality (number of deaths) } \\
Culiacan & 105 & 158 & 212 & 138 & 207 & 276 \\
Mazatlan & 169 & 253 & 337 & 187 & 281 & 335 \\
Total & $\mathbf{4 2 8}$ & $\mathbf{6 3 8}$ & $\mathbf{8 5 2}$ & $\mathbf{4 9 2}$ & $\mathbf{7 3 9}$ & $\mathbf{9 8 6}$ \\
\hline
\end{tabular}

Cardiovascular mortality (number of deaths)

\begin{tabular}{lcccccc}
\hline Culiacan & 57 & 85 & 113 & 74 & 111 & 148 \\
Los Mochis & 88 & 132 & 176 & 97 & 145 & 193 \\
Mazatlan & 85 & 127 & 169 & 94 & 140 & 189 \\
Total & $\mathbf{2 3 0}$ & $\mathbf{3 4 4}$ & $\mathbf{4 5 8}$ & $\mathbf{2 6 5}$ & $\mathbf{3 9 6}$ & $\mathbf{5 3 0}$ \\
\hline
\end{tabular}

Gain in life expectancy (months)

\begin{tabular}{lcccccc}
\hline Culiacan & 3 & 5 & 7 & 5 & 7 & 9 \\
Los Mochis & 8 & 13 & 19 & 9 & 15 & 22 \\
Mazatlan & 8 & 13 & 19 & 9 & 15 & 22 \\
\hline
\end{tabular}




\section{Economic evaluation}

403 The VSL calculated for Mexico was between \$453,435 USD (minimum), \$939,894 USD (mean)

404 and $\$ 1,948,243$ (maximum). With an income elasticity equal to 1.5 , we decided to utilize the mean

405 value to estimate the economic cost of air pollution by $\mathrm{PM}_{2.5}$. Under the NOM scenario, the

406 economic impact due to total mortality was \$148.6, \$213.3 and \$237.8 million USD for Culiacan,

407 Los Mochis and Mazatlan, respectively. The total cost of total mortality for the three cities was

408 \$599.7 million USD. Using the NOM scenario, the economic cost of cardiovascular deaths was

$409 \$ 79.9, \$ 124.1$ and $\$ 119.4$ million USD for Culiacan, Los Mochis and Mazatlan with a total cost

410 equivalent to $\$ 323.3$ million USD (Table 3). Using the WHO scenario, the economic impact

411 caused by total mortality (mean) was \$194.6, \$235.9 and \$264.1 million USD for Culiacan, Los

412 Mochis and Mazatlan, totaling \$694.6 million USD for these three cities. For cardiovascular death,

413 the economic cost was \$104.3 for Culiacan, \$136.2 for Los Mochis and \$131.6 for Mazatlan with

414 a total amount of $\$ 372.2$ million USD (Table 3). The overall economic cost per year of the PM2.5

415 effects on human life in these three Sinaloa's cities was estimated on about \$599.7 and \$694.6

416 million USD, for the NOM and WHO scenarios, respectively. 
426 Table 3 Economic impacts of mortality by avoidable total and cardiovascular mortality in the studied 427 cities (USD) ${ }^{\mathrm{a}}$

Cities

Scenario NOM

Min.

Mean

Max.

Min.

Scenario WHO

Total mortality

\begin{tabular}{|c|c|c|c|c|c|c|}
\hline Culiacan & $98,688,870$ & $148,503,252$ & $199,257,528$ & $129,705,372$ & $194,558,058$ & $\begin{array}{r}259,410,7 \\
44\end{array}$ \\
\hline $\begin{array}{l}\text { Los } \\
\text { Mochis }\end{array}$ & $144,743,676$ & $213,355,938$ & $284,787,882$ & $156,962,298$ & $235,913,394$ & $314,864,490$ \\
\hline Mazatlan & $158,842,086$ & $237,793,182$ & $316,744,278$ & $175,760,178$ & $264,110,214$ & $352,460,250$ \\
\hline Total & $402,274,632$ & $599,652,372$ & $800,789,688$ & $462,427,848$ & $694,581,666$ & $926,735,484$ \\
\hline
\end{tabular}

Cardiovascular mortality

\begin{tabular}{lrrrrrr}
\hline Culiacan & $53,573,958$ & $79,890,990$ & $106,208,022$ & $69,552,156$ & $104,328,234$ & $139,104,312$ \\
& & & & & & \\
Los & $82,710,672$ & $124,066,008$ & $165,421,344$ & $91,169,718$ & $136,284,630$ & $181,399,542$ \\
Mochis & & & & & & \\
Mazatlan & $79,890,990$ & $119,366,538$ & $158,842,086$ & $88,350,036$ & $131,585,160$ & $177,639,966$ \\
& & & & & & \\
Total & $216,175,620$ & $323,323,536$ & $430,471,452$ & $249,071,910$ & $372,198,024$ & $498,143,820$
\end{tabular}

429

430

${ }^{a}$ The calculated VSL value for Mexico is $\$ 939,894$ (USD, 2017).

431

432

433 
434 These costs were elevated because air pollution levels in these Sinaloa's cities exceeded 435 significantly the NOM [50] and WHO [66] permissible levels. Further examination of air quality 436 and pollution would include a cost-benefit analysis to compare these estimated costs with the

437 benefits of allocating monetary resources to public policy aiming to mitigate and control this 438 environmental deterioration.

\section{Discussion}

441 There is a shortage of HIA studies exploring the environmental impact caused by poor air quality

442 in Mexican cites and developing countries in general. This work focused on settlements with less 443 than one million residents to prove that a sample of three cities in the northwestern (Sinaloa),

444 Mexico have $\mathrm{PM}_{2.5}$ average concentrations way above the recommended national [50] and 445 international [66] guidelines, causing harm to human health that can be avoided. It is worth 446 mentioning that the city with the largest population (Culiacan) experience the lowest economic 447 impact, compared to the other two cities. A plausible explanation is that Culiacan, as the State 448 capital, has few fix sources of emission such as low levels of industrialization, low population

449 density (144 inhabitants per $\mathrm{km}^{2}$ ), favorable geographic location and compass rose among other 450 factors. Conversely, Los Mochis and Mazatlan have comparable and substantially higher rates of 451 avoidable death than Culiacan. These two cities have thermal power stations to produce electricity 452 operating with a toxic pollutant fossil fuel known as "combustoleo", a by-product in the oil refining 453 process. Besides, Mazatlan and Los Mochis are heavy traffic seaports moving high volumes of 454 containerized and in bulk cargo; these cities are also the headquarters of local companies and have 455 pipelines that facilitate environmental pollution caused by oil. In the case of Los Mochis city, this 456 situation can worsen due to the planned installation of an ammonia production plant near the city 
$457(\sim 20 \mathrm{~km})$, at the margin of the Ohuira-Topolobampo lagoon complex. This plant will produce

458770,000 tons of ammonia per year using natural gas, a less toxic than other fossil fuels, however,

459 is expected to increase the emission of $\mathrm{H}_{2}, \mathrm{CO}_{2}, \mathrm{NH}_{3}, \mathrm{CO}, \mathrm{H}_{2} \mathrm{~S}$ and $\mathrm{PM}_{2.5}$ [52], adding this impact

460 to that caused by the thermal power plant.

461 Although the HIA methodology is solid [56,57], there are some features that we were unable to

462 capture in our analysis, such as the representativeness of the population and other possible forms

463 of the CRF. We argue that value of the impact to chronic exposure of $\mathrm{PM}_{2.5}$ on health was likely

464 underestimated because of the variations of the pollutant within a city, particularly in urban areas

465 with heavy traffic and around specific industries and the thermal power plants, like in Mazatlan

466 and Los Mochis. Our findings suggest that variations in air quality within a city can be wider than

467 those variations across cities $[43,53]$. Also, the use of TEOM technologies to measure particulate

468 matter may underestimate the real exposure because of its intermittence, even when using a factor

469 for local correction. The CRF of the US American Cancer Society provides the best available

470 evidence regarding the long-term effect of chronic pollution exposure by $\mathrm{PM}_{2.5}[56,45,46]$.

471 European cohort studies [7] and Canadian analyses have found similar relative risk ratios [16].

472 Our HIA results show estimations of the number of avoidable deaths in three different cities in

473 northwestern Mexico as well as its corresponding money values, demonstrating the benefits of

474 reducing pollution levels at or below the NOM [50] and WHO [66] recommended guidelines, thus

475 our initial hypothesis was accomplished. The findings of this study can contribute policy on the

476 economic and human cost of air pollution; thus, complying with the Official Mexican Standard

477 and the "ProAire" program guidelines implemented by the Mexico's Secretariat of Environment

478 and Natural Resources [59] would decrease the number of avoidable deaths with its commensurate 
479 gains in life expectancy in these three Mexican cities. Estimating the economic cost of pollution 480 may have a great social impact and is beneficial in terms of public health.

\section{Conclusions}

483 Using the HIA strategy we estimate the total avoidable deaths associated with air pollution and 484 computed the economic costs for three northwestern Mexican cities. These findings allow us to 485 know the total cost derived from air pollution attributable to $\mathrm{PM}_{2.5}$ and better understand the 486 benefits of reducing environmental pollution below the maximum allowed under two scenarios.

487 Under the NOM [50] scenario, we determined that 638 deaths could be avoided (158 in Culiacan, 488227 in Los Mochis and 253 in Mazatlan). We also established that life expectancy would increase 489 in 5, 13 and 13 months for people in these cities in the same order. Regarding the WHO [66] 490 scenario, total avoidable deaths were 739 in our sample of cities, being 207 in Culiacan, 251 in 491 Los Mochis and 281 in Mazatlan, with a corresponding gain in the mean life expectancy of 7, 15 492 and 15 in the same order. We quantified the average cost of the impact on health as a result of $493 \quad \mathrm{PM}_{2.5}$ with value around $\$ 600$ and $\$ 695$ million USD. However, we consider that the figures 494 aforesaid were underestimated because it does not itemize important evaluation features such as 495 morbidity, loss of productivity, number of days absent at work, and population younger than 30 496 years of age. Our results contribute to the existing empirical body of evidence emphasizing the 497 economic and social benefits of abiding federal and state environmental policies aiming to reduce 498 current levels of environmental pollution by $\mathrm{PM}_{2.5}$ in these three Mexican cities. Thus, controlling 499 air pollution is socially beneficial and the role of environmental and public policies are key to 500 ameliorate the effect of the $\mathrm{PM}_{2.5}$ pollutants. 
Supplementary information accompanies this paper

503 Appendix A: Procedure to Estimate Gains in Life Expectancy

504

505

506

507

508

509

510

511

512

513

514

515

516

517

518

519

520

521

522

523

524

525

526

527

528

529

530

531

532

533

534

535

536

537

538

539

540

541

542

543

544

545

546

547

\section{Abbreviations}

ACS: American Cancer Society; Aphekom: Tool designed by the European Aphekom Project to quantify the impact of air pollution on human health; CI: Confidence Interval; CRF: Concentration-Response Function; GDP: Gross Domestic Product; HIA: Health Impacts Assessment; ICD-10: International Classification of Diseases; IHEM: Institute for Health Metrics and Evaluation, University of Washington, Seattle; INECC: National Institute of Ecology and Climate Change (Spanish acronym); INEGI: National Institute of Statistics and Geography (Spanish acronym); NOM scenario: $12 \mu \mathrm{g} / \mathrm{m}^{3}$ (NOM-025-SSA1-2014); NOM: Official Mexican Standard (Spanish acronym); OECD: Organization for Economic Co-operation and Development; $\mathrm{PM}_{2.5}$ : particulate matter suspended in the air with an aerodynamic diameter of at most 2.5 micrometers $(\mu \mathrm{m})$; RR; Relative Risk; TEOM: Tapered Element Oscillating Microbalances technology; US: United States of America; USD: United States of America Dollar; VSL: Value of a Statistical Life; WB: World Bank; WHO scenario: $10 \mu \mathrm{g} / \mathrm{m}^{3}$ (WHO, 2006); WHO: World Health Organization; $\mu$ m: micrometers.

\section{Acknowledgements}

We would like to thank the National Council of Science and Technology of Mexico for the scholarship awarded to RARA.

\section{Authors' contributions}

Conceptualization and study design: LABP and RARA; review of literature and drafting: LABP and RARA; writing-review and editing: LABP, JDC, FPO, BGP, JGCL and EB; field and laboratory work: LABP and RARA; software: EB; resources, funding acquisition, supervision, and project administration: LABP.

\section{Funding}

This research did not receive any specific grant from funding agencies in the public, commercial, or not-for-profit sectors.

\section{Availability of data and materials}

The datasets used and/or analyzed during the current study are available from the corresponding author on request.

\section{Declarations}

Ethics approval and consent to participate

Not applicable

\section{Consent for publication}

Not applicable

\section{Competing interests}

The authors declare no conflict of interest. 


\section{References}

1. Anenberg SC, Horowitz LW, Tong DQ, West JJ (2010) An Estimate of the Global Burden of Anthropogenic Ozone and Fine Particulate Matter on Premature Human Mortality Using Atmospheric Modeling. Environ Health Perspect 118: 1189-1195. https://doi.org/10.1289/ehp.0901220

2. Aphekom Project (2013) Health Impact Assessment Tool Long Term. www.aphekom.org. Accessed 10 January 2020

3. Aphekom (2013) The Aphekom Project Improving knowledge and communication for decision making on air pollution and health in Europe. http://aphekom.org/c/document_library/get_file?uuid=3f436766-812c-4658-a901ca52ee5d8e35\&groupId=10347. Accessed 20 August 2019

4. Arriagada NB, Horsley JA, Palmer AJ, Morgan GG, Tham R, Johnston FH (2019) Association between fire smoke fine particulate matter and asthma-related outcomes: Systematic review and meta-analysis. Environ Res 179: 108777. https://doi.org/10.1016/j.envres.2019.108777

5. Barret RH, Speth RL, Eastham SD, Dedoussi IC, Ashok A, Malina R, Keith DV (2015) Impact of the Volkswagen emissions control defeat device on US public health. Environ Res Lett 10: 114005. https://doi.org/10.1088/1748-9326/10/11/114005

6. Becerra-Pérez LA, Ramos-Álvarez RA (2020) Evaluación del Impacto en la Salud por Partículas $\mathrm{PM}_{2.5}$ en Sinaloa, México. Rev Int Contam Ambie 36 (2): 249259. http://dx.doi.org/10.20937/RICA.53463

7. Beelen R, Hoek G, van den Bravndt PA, Goldbohm RA, Fischer P, Schouten LJ, Jerret M, Hughes E, Armstrong B, Brunekreef B (2008) Long-term effects of traffic-related air 
pollution on mortality in a Dutch cohort [NLCS-AIR study]. Environ Health Perspect 116:

573

574

575

576

577

578

579

580

581

582

583

584

585

586

587

588

589

590

591

592

593

594

\section{6-202. https://doi.org/10.1289/ehp.10767}

8. Brook RD, Rajagopalan S, Pope CA, Brook JR, Bhatnagar A, Diez-Roux AV, Holguin F, Hong Y, Luepker RV, Mittleman MA, Peters A, Siscovick D, Smith SC Jr, Whitsel L, Kaufman JD (2010) Particulate matter air pollution and cardiovascular disease: An update to the scientific statement from the American Heart Association. Circ 121: 2331-2378. https://doi.org/10.1161/CIR.0b013e3181dbece1

9. Burkhardt J, Bayham J, Wilson A, Carter E, Berman JD, O’Dell K, Ford B, Fischer EV (2019) The effect of pollution on crime: evidence from data on particulate matter and ozone. Journal of Environmental Economics and Management 98: 102267

10. Chanel O, Henschel S, Goodman P, Analitis A, Atkinson RW, Le Tertre A, Zeka A, Medina S, Aphekom group (2014). Economic valuation of the mortality benefits of a regulation on $\mathrm{SO}_{2}$ in 20 European cities. Eur J Public Health 24: 631-637. https://doi.org/10.1093/eurpub/cku018

11. Chanel O, Perez P, Künzli K, Medina S, Aphekom Group (2016) The hidden economic burden of air pollution-related morbidity: evidence from the Aphekom project. Eur J Health Econ 17: 1101-1115. https://doi.org/10.1007/s10198-015-0748-Z

12. Chun H, Leung C, Wen SW, McDonald J, Shin HH (2020) Maternal exposure to air pollution and risk of autism in children: A systematic review and meta-analysis. Environ Pollut 256: 113307. https://doi.org/10.1016/j.envpol.2019.113307

13. Cohen AJ, Brauer M, Burnett R, Anderson HR, Frostad J, Estep K, Balakrishnan K, Brunekreef B, Dandona L, Dandona R, Feigin V, Freedman G, Hubbell B, Jobling A, Kan H, Knibbs L, Liu Y, Martin R, Morawska L, Pope CA, Shin H, Straif K, Shaddick G, 
Thomas M, Dingenen R, Van Donkelaar A, Van Vos T, Murray C JL, Forouzanfar MH (2017) Estimates and 25-year trends of the global burden of disease attributable to ambient air pollution: an analysis of data from the Global Burden of Diseases Study 2015. Lancet 389: 1907-1918. https://doi.org/10.1016/S0140-6736(17)30505-6

14. CONAPO (2017) Proyección de la población de México y de las Entidades Federativas, 2016-2050.

Consejo

Nacional

de

Población,

México.

https://www.gob.mx/conapo/acciones-y-programas/conciliacion-demografica-de-mexico$\underline{\text { 1950-2015-y-proyecciones-de-la-poblacion-de-mexico-y-de-las-entidades-federativas- }}$ 2016-2050. Accessed 20 April 2019

15. Crippa M, Janssens-Maenhout G, Guizzardi D, Van Dingenen R, Dentener F (2019) Contribution and uncertainty of sectorial and regional emissions to regional and global $\mathrm{PM}_{2.5}$ health impacts. Atmos Chem Phys 19: 5165-5186. https://doi.org/10.5194/acp-19$\underline{5165-2019}$

16. Crouse L, Peters PA, Van Donkelaar A, Goldberg MS, Villeneuve PJ, Brion O, Khan S, Atari DO, Jerret M, Pope CA, Brauer M, Brook JR, Martin RV, Stieb D, Burnett RT (2012) Risk of nonaccidental and cardiovascular mortality in relation to long-term exposure to low concentrations of fine particulate matter: a Canadian national-level cohort study. Environ Health Perspect120: 708-714. https://doi.org/10.1289/ehp.1104049 Benach J, Cirach M, Dadvand P, Ghigo S, Martínez-Solanas E, Nieuwenhuijsen M, Cadum E, Basagaña X (2017) The association of air pollution and greenness with mortality and life expectancy in Spain: A small-area study. Environ Int 99: 170-176. https://doi.org/10.1016/j.envint.2016.11.009 
18. De Lima M (2019) The value of a statistical life in México. J Environ Econ Policy 9: 140166. https://doi.org/10.1080/21606544.2019.1617196

19. Declercq C, Pascal M, Corso M, Ung M, Medina S, on behalf of the Aphekom WP5 team (2011) Health impacts of urban air pollution in 25 European cities. http://www.aphekom.org/c/document_library/get_file?uuid=4f388abf-61e5-415d-ae22-

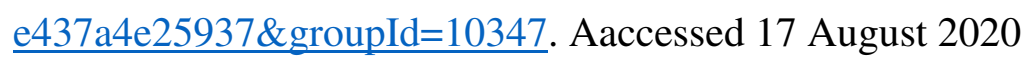

20. European Centre for Health Policy (1999) Health Impact Assessment: main concepts and suggested approach.

Gothenburg consensus paper, Brussels. https://web.archive.org/web/20061007033923/http://www.who.dk/document/PAE/Gothe nburgpaper.pdf. Accessed 15 February 2020 Yang BY, Dong GH (2020) Ambient air pollution and depression: A systematic review with meta-analysis up to 2019. Sci Total Environ 701: 134721. https://doi.org/10.1016/j.scitotenv.2019.134721

22. Forouzanfar MH, Alexander L, Anderson HR, Bachman VF, Biryukov S, Brauer M, Burnett R, Casey D, Coates MM, Cohen A, Delwiche K, Estep K, Frostad JJ, Astha KC, Global, regional, and national comparative risk assessment of 79 behavioral, environmental and occupational, and metabolic risks or clusters of risks in 188 countries, 1990-2013: a systematic analysis for the Global Burden of Disease Study 2013. Lancet 386: 2287-2323. https://doi.org/10.1016/S0140-6736(15)00128-2

23. GBD Results (2017) Global Burden of Disease Study, 2017. https://vizhub.healthdata.org/gbd-compare/. Accessed 28 May 2020 
24. Guyatt G, Jaeschke R, Heddle N, Cook D, Shannon H, Walter S (1995) Basic statistics for clinicians [Interpreting study results: confidence intervals]. CMAJ [Canadian Medical Association Journal] 152(2): 169-173.

25. Hammitt JK, Robinson LA (2011) The income elasticity of the value per statistical life: transferring estimates between high and low income populations. J Benefit-Cost Anal 2: 129. https://doi.org/10.2202/2152-2812.1009

26. Han C, Lu Y, Cheng H, Wang C, Chan P (2020) The impact of long-term exposure to ambient air pollution and second-hand smoke on the onset of Parkinson disease: a review and meta-analysis. Public Health 179:100-110. https://doi.org/10.1016/j.puhe.2019.09.020

27. Han F, Yang X, Xu D, Wang Q, Xu D (2019) Association between outdoor PM2.5 and prevalence of COPD: a systematic review and meta-analysis. Post Med J 95: 612-618. https://doi.org/10.1136/postgradmedj-2019-136675

28. Hassoun Y, James C, Bernstein DI (2019) The effects of air pollution on the development of atopic disease. Clin Rev Allergy Immun 57: 403-414. https://doi.org/10.1007/s12016$\underline{019-08730-3}$

29. Henschel S, Atkinson R, Zeka A, Le Tertre A, Analitis A, Katsouyanni K, Chanel O, Pascal M, Forsberg B, Medina S, Goodman PG (2012) Air pollution interventions and their impact on public health. Int J Public Health 57: 757-768. https://doi.org/10.1007/s00038-012$\underline{0369-6}$

661

30. Henschel S, Querol X, Atkinson R, Pandolfi M, Zeka A, Le Tertre A, Analitis A, Katsouyanni K, Chanel O, Pascal M, Bouland C, Haluza D, Medina S, Goodman PG (2014) Ambient air $\mathrm{SO}_{2}$ patterns in 6 European cities. Atmos Environ 79: 236-247. https://doi.org/10.1016/j.atmosenv.2013.06.008 
31. Heyes A, Zhu M (2019) Air pollution as a cause of sleeplessness: social media evidence from a panel of Chinese cities. J of Environ Economics and Management 98: 102247.

32. Hoek G, Krishnan RM, Beelen R, Peters A, Ostro B, Brunekreef B, Kaufman JD (2013) Long-term air pollution exposure and cardio- respiratory mortality: a review. Environ Health 12: 43. https://doi.org/10.1186/1476-069X-12-43

33. IHME, World Bank (2016) The Cost of Air Pollution: Strengthening the Economic Case for Action (English), Washington, DC, World Bank Group, Report Number 108141, Volume No 1. https://documents.worldbank.org/en/publication/documentsreports/documentdetail/781521473177013155/the-cost-of-air-pollution-strengtheningthe-economic-case-for-action. Accessed 20 June 2019 Kioutsioukis I, Alyuz U, Balzarini A, Baro R, Bellasio R, Bianconi R, Bieser J, Colette A, Curci G, Farrow A, Flemming J, Fraser A, Jimenez-Guerrero P, Kitwiroon N, Liang CK, Nopmongcol U, Pirovano G, Pozzoli L, Prank M, Rose R, Sokhi R, Tuccella P, Unal A, Vivanco MG, West J, Yarwood G, Hogrefe C, Galmarini S (2018) Assessment and economic valuation of air pollution impacts on human health over Europe and the United States as calculated by a multimodel ensemble in the framework of AQMEII3. Atmos Chem Phys 18: 5967-5989. https://doi.org/10.5194/acp-18-5967-2018

35. INECC (2014) Valoración económica de los beneficios a la salud de la población que se alcanzarían por la reducción de las PM2.5 en tres zonas metropolitanas mexicanas. INECC, México.https://www.gob.mx/cms/uploads/attachment/file/195224/2014_CGCSA_Benefi cos_econ_micos_al_reducir_PM2.5.pdf. Accessed 15 March 2020 
36. INECC (2017) Estimación de impactos en la salud por contaminación atmosférica en la región centro del país y alternativas de gestión. INECC, México. http://cambioclimatico.gob.mx:8080/xmlui/bitstream/handle/publicaciones/52/738_2017_ Estimacion_impactos_contaminacion_atmosferica_centropais.pdf?sequence=1\&isAllowe $\underline{\mathrm{d}=\text { Accessed. }}$. Accessed 15 March 2020

37. INEGI (2015) Densidad de población. Instituto Nacional de Estadística y Geografía. https://www.inegi.org.mx/app/buscador/default.html?q=densidad+de+poblacion\#tabMCc ollapse-Indicadores. Accessed 17 January 2020

38. INEGI (2017) Anuario estadístico y geográfico de Sinaloa 2017. http://www.internet.contenidos.inegi.org.mx/contenidos/Productos/prod_serv/contenidos/ espanol/bvinegi/productos/nueva_estruc/anuarios_2017/702825094898.pdf. Accessed 25 February 2020

39. INEGI (2017) Información sobre el volumen de las defunciones registradas en el país, así como algunas características por edad y sexo de los fallecidos y las principales causas que originan los decesos. https://www.inegi.org.mx/temas/mortalidad/. Accessed 8 March 2020

40. INEGI (2018) Anuario estadístico y geográfico por entidad federativa 2018. http://internet.contenidos.inegi.org.mx/contenidos/Productos/prod_serv/contenidos/espan

41. INEGI (2018) Cuentas Económicas y Ecológicas de México. DGAdeC, INEGI. https://www.inegi.org.mx/contenidos/saladeprensa/boletines/2019/StmaCntaNal/CtasEc

$708 \quad$ mcasEcolgicas2018.pdf. Accessed 22 May 2020 
42. INEGI (2010) Censo de Población y 2010. https://www.inegi.org.mx/programas/ccpv/2010/. Accessed 8 May 2020

43. Jerrett M, Burnett RT, Ma R, Pope CA, Krewski D, Newbold KB, Thurston G, Shi Y, Finkelstein N, Calle EE, Thun MJ (2005) Spatial analysis of air pollution and mortality in

713 Los Angeles. Epidemiol

16: $727-736$. https://doi.org/10.1097/01.ede.0000181630.15826.7d

715

44. Jin Y, Andersson H, Zhang S (2020) Do preferences to reduce health risks related to air Journal of Environmental Economics and Management 103: 102355.

45. Krewski D, Jerrett M, Burnett RT, Ma R, Hughes E, Shi Y, Thun MJ (2009) Extended follow-up and spatial analysis of the American Cancer Society study linking particulate air pollution and mortality [No. 140]. Boston, MA: Health Effects Institute. https://www.healtheffects.org/publication/extended-follow-and-spatial-analysisamerican-cancer-society-study-linking-particulate. Accessed 13 June 2020

46. Laden F, Schwartz J, Speizer FE, Dockery DW (2006) Reduction in fine particulate air pollution and mortality: Extended follow-up of the Harvard Six Cities study. Am J Respir Crit Care Med 173: 667-672. https://doi.org/10.1164/rccm.200503-4430C

726 47. Le Tertre A, Henschel S, Atkinson RW, Analitis A, Zeka A, Katsouyanni K, Goodman P, Medina S (2014) Impact of legislative changes to reduce the sulphur content in fuels in Europe on daily mortality in 20 European cities: an analysis of data from the Aphekom Project. Air Qual Atmos Health 7: 83-91. https://doi.org/10.1007/s11869-013-0215-X 
48. Lelieveld J, Evans JS, Fnais M, Giannadaki D, Pozzer A (2015) The contribution of outdoor air pollution sources to premature mortality on a global scale. Nature 525: 367-371. https://doi.org/10.1038/nature15371

49. Montori VM, Kleinbart J, Newman TB, Keitz S, Wyer PC, Moyer V, Guyatt G, Evidencemedicine: Measures of precision [confidence intervals]. CMAJ [Canadian Medical Association Journal] 171(6): 611-615. https://doi.org/10.1503/cmaj.1031667

50. NOM-025-SSA1-2014 [Norma Oficial Mexicana, salud ambiental] (2014) Valores límite permisibles para la concentración de partículas suspendidas $\mathrm{PM}_{10}$ y $\mathrm{PM}_{2.5}$ en el aire ambiente y criterios para su evaluación. Secretaría de Salud, DOF. https://www.dof.gob.mx/nota_detalle.php?codigo $=5357042 \&$ fecha=20/08/2014.

Accessed 20 January 2020

51. Organization for Economic Co-operation and Development (2016) The economic consequences of outdoor air pollution. OECD Publishing, Paris. https://www.oecd.org/environment/indicators-modelling-outlooks/Policy-Highlights-

Economic-consequences-of-outdoor-air-pollution-web.pdf. Accessed 27 March 2020

52. Páez-Osuna F, Flores-Campaña LM, Karam-Quiñones C, Páez-Michel AL, SaucedoBarrón JC, Zavala-Norzagaray A, Osuna-Martínez CC, Becerra-Pérez LA (2018) Alternatives for reducing the environmental impact of an ammonia production plant adjacent to a coastal lagoon in the southeastern Gulf of California. J Cleaner Prod 200: 960-970. https://doi.org/10.1016/j.jclepro.2018.08.020

53. Pascal M, Corso M, Chanel O, Declercq C, Badaloni C, Cesaroni G, Henschel S, Meister K, Haluza D, Martin-Olmedo P, Medina S (2013) Assessing the public health impacts of 
urban air pollution in 25 European cities: results of the Aphekom Project. Sci Total Environ 449: 390-400. https://doi.org/10.1016/j.scitotenv.2013.01.077

54. Peng F, Tsuji G, Zhang JZ, Chen Z, Furue M (2019) Potential role of $\mathrm{PM}_{2.5}$ in melanogenesis. Environ Int 132: 105063. https://doi.org/10.1016/j.envint.2019.105063

757 55. Perez L, Declercq C, Iñiguez C, Aguilera I, Badaloni Ch, Ballester F, Bouland C, Chanel O, Cirarda FB, Forastiere F, Forsberg B, Haluza D, Hedlund B, Koldo C, Lacasaña M, Moshammer H, Otorepec P, Rodríguez-Barranco M, Medina S, Künzli N (2013) Chronic Resp J 42: 594-605. https://doi.org/10.1183/09031936.00031112

56. Pope CA, Burnett RT, Thun MJ, Calle EE, Krewski D, Kazuhiko I, Thurston GD (2002) Lung cancer, cardiopulmonary mortality, and long-term exposure to fine particulate air pollution. JAMA 287: 1132-1141. https://doi.org/10.1001/jama.287.9.1132

57. Pope CA, Burnett RT, Thurston GD, Thun MJ, Calle EE, Krewski D, Godleski JJ (2004) Cardiovascular mortality and long-term exposure to particulate air pollution: epidemiological evidence of general pathophysiological pathways of disease. Cir 109: 7177. https://doi.org/10.1161/01.CIR.0000108927.80044.7F

58. Pope CA, Dockery DW (2006) Health effects of fine particulate air pollution: lines that connect. Air Waste Manage Assoc 56: $\quad 709-742$. https://doi.org/10.1080/10473289.2006.10464485

59. SEMARNAT (2018) Programas de Gestión para Mejorar la Calidad del Aire en Sin 20182028 https://www.gob.mx/cms/uploads/attachment/file/300694/21_ProAire_Sinaloa.pdf.

774 Accessed 11 January 2020 
60. Trejo-González AG, Riojas-Rodriguez H, Texcalac-Sangrador JL, Guerrero-López CM, Cervantes-Martínez K, Hurtado-Díaz M, Zuñiga-Bello PE (2019) Quantifying health impacts and economic costs of $\mathrm{PM}_{2.5}$ exposure in Mexican cities of the National Urban System. Int J Public Health 64: 561-572. https://doi.org/10.1007/s00038-019-01216-1 Fine particulate matter is a potential determinant of Alzheimer's disease: A systemic review and meta-analysis. Environ Res 177:108638. https://doi.org/10.1016/j.envres.2019.108638

62. Tsoli S, Ploubidis GB, Kalantzi OI (2019) Particulate air pollution and birth weight: A 783 systematic literature review. Atmos Pollut Res 10: 1084-1122. https://doi.org/10.1016/j.apr.2019.01.016

63. US Environmental Protection Agency (2011) The Benefits and Costs of the Clean Air Act: 1990 to 2020. Final report of US Environmental Protection Agency Office of Air and Radiation. https://www.epa.gov/clean-air-act-overview/benefits-and-costs-clean-air-act1990-2020-report-documents-and-graphics. Accessed 12 January 2020

64. Whitley E, Ball J (2002) Statistics review 2: Samples and populations. Critical Care 7(1): 8. https://doi.org/10.1186/cc1867

791

65. World Bank

(2017) World

Development

Report, New York. https://www.worldbank.org/en/publication/wdr/wdr-archive. Accessed 12 January 2020

66. World Health Organization (2006) Air quality guidelines for particulate matter, ozone, February 2020 
67. World Health Organization (2013) Review of Evidence on Health Aspects of Air Pollution -REVIHAAP- First Results. WHO Regional Office for Europe. http://www.euro.who.int/__data/assets/pdf_file/0004/193108/REVIHAAP-Finaltechnical-report.pdf. Accessed 9 April 2020

68. World Health Organization (2016) Ambient air pollution: A global assessment of exposure and burden of disease.

WHO

Geneva

Switzerland. https://www.who.int/phe/publications/air-pollution-global-assessment/en/. Accessed 15 April 2020

805

69. Wu MY, Lo WC, Chao CT, Wu MS, Chiang CK (2020) Association between air pollutants and development of chronic kidney disease: A systematic review and meta-analysis. Sci Total Environ 706: 135522. https://doi.org/10.1016/j.scitotenv.2019.135522

70. Wu R, Dai H, Geng Y, Xie Y, Masui T, Liu Z, Qian Y (2017) Economic Impacts from PM2.5 Pollution-Related Health Effects: A Case Study in Shanghai. Environ Sci Technol 51: 5035-5042. https://doi.org/10.1021/acs.est.7b00026

71. Yang BY, Fan S, Thiering E, Seissler J, Nowak D, Dong GH, Heinrich J (2020) Ambient air pollution and diabetes: a systematic review and meta-analysis. Environ Res 180: 108817. https://doi.org/10.1016/j.envres.2019.108817

72. Yuan S, Wang J, Jiang Q, He Z, Huang Y, Li Z, Cai L, Cao S (2019) Long-term exposure to $\mathrm{PM}_{2.5}$ and stroke: A systematic review and meta-analysis of cohort studies. Environ Res 177: 108587. https://doi.org/10.1016/j.envres.2019.108587

73. Zhang Z, Yan W, Chen Q, Zhou N, Xu Y (2019) The relationship between exposure to particulate matter and breast cancer incidence and mortality: A meta-analysis. Med 98. https://doi.org/10.1097/MD.0000000000018349 
820 74. Zuk M, Garibay V, Iniestra R, López MT, Rojas L, Laguna I (2006) Introducción a la 821 evaluación de los impactos de las termoeléctricas de México: Un estudio de caso en Tuxpan, Veracruz. Instituto Nacional de Ecología. http://cambioclimatico.gob.mx:8080/xmlui/bitstream/handle/publicaciones/130/496_2006 _Intr_evaluacion_impactos_termoelectricas_Mexico.pdf?sequence=1\&isAllowed=y.

$825 \quad$ Accessed 5 May 2020

826 


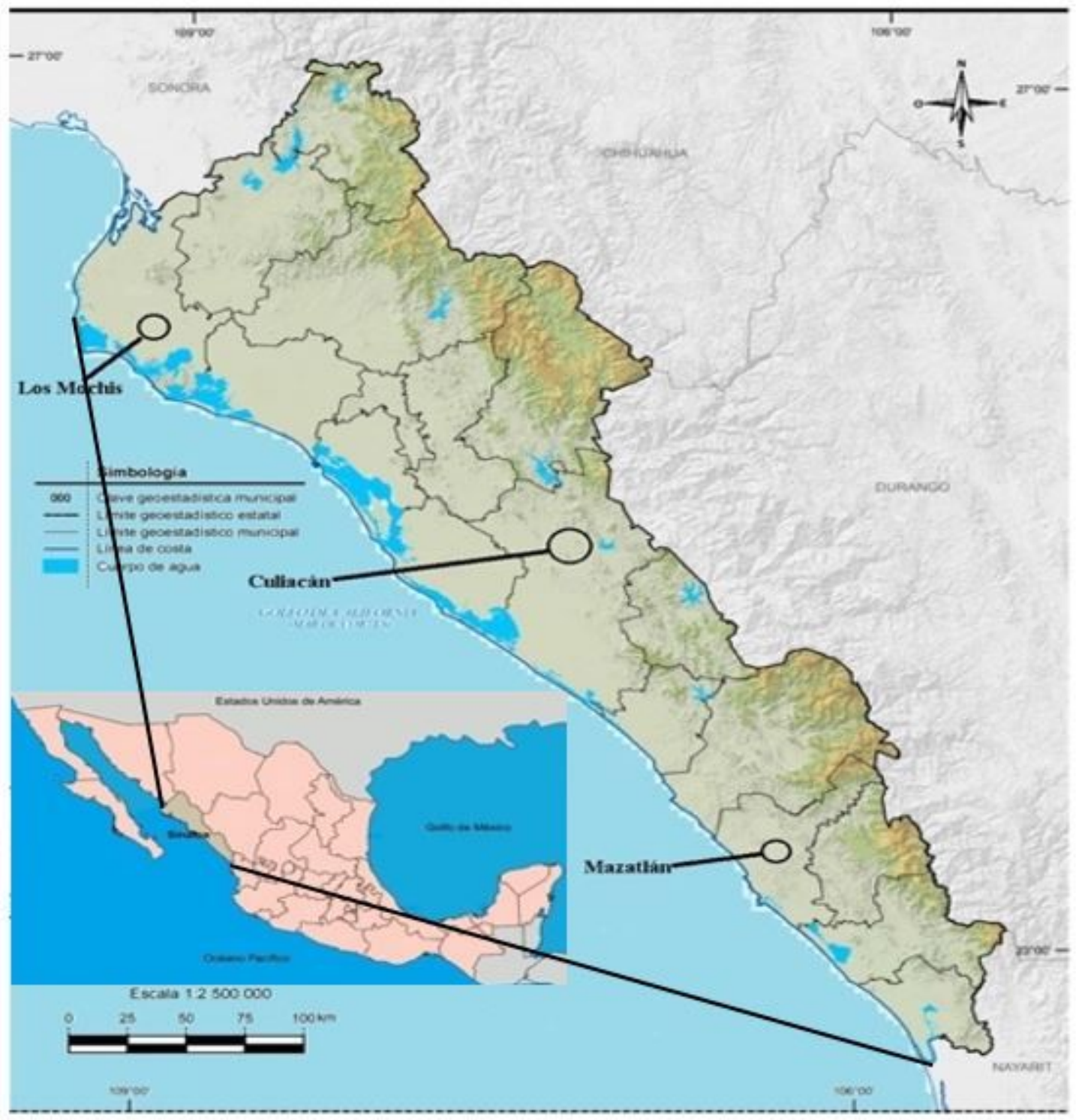

\section{Figure 1}

Location of the three cities examined: Culiacan, Los Mochis and Mazatlan [38] Note: The designations employed and the presentation of the material on this map do not imply the expression of any opinion whatsoever on the part of Research Square concerning the legal status of any country, territory, city or area or of its authorities, or concerning the delimitation of its frontiers or boundaries. This map has been provided by the authors. 
(a)

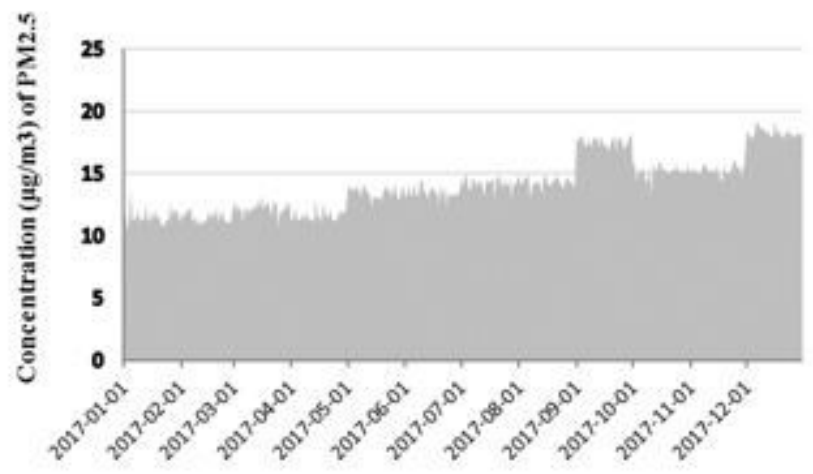

(b)

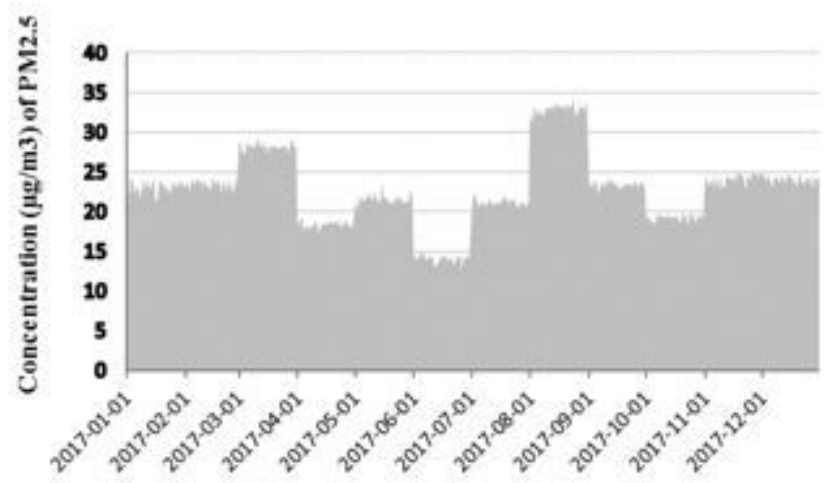

(c)

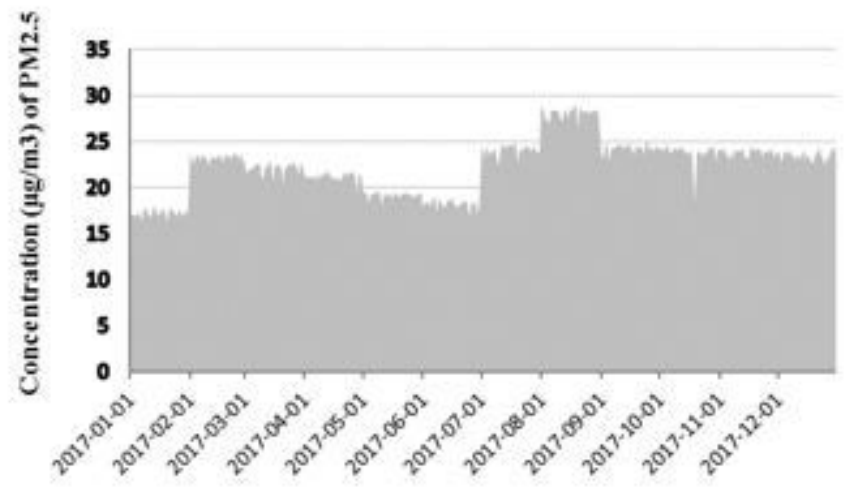

Figure 2

PM2.5 Daily average concentrations $(\mu \mathrm{g} / \mathrm{m} 3)$ in cities participating in the study (a) Culiacan, (b) Los Mochis, (c) Mazatlan during 2017 
(a)

\section{Impacts of PM2.5}

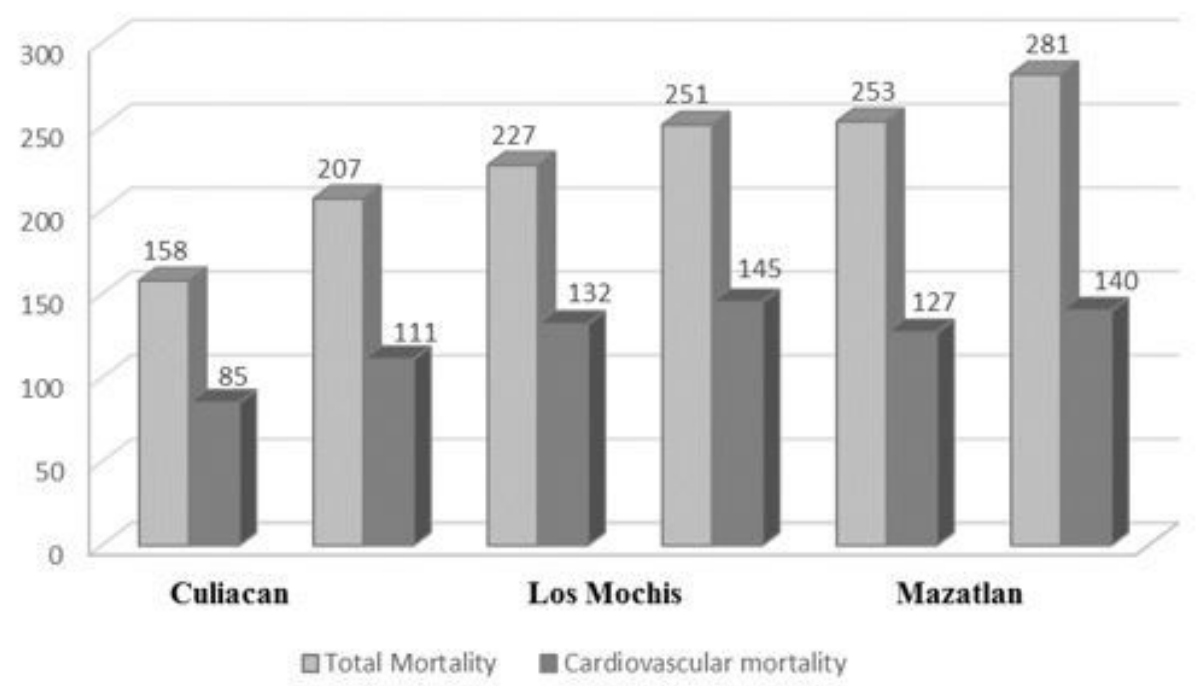

(b)

\section{Impacts of PM2.5}

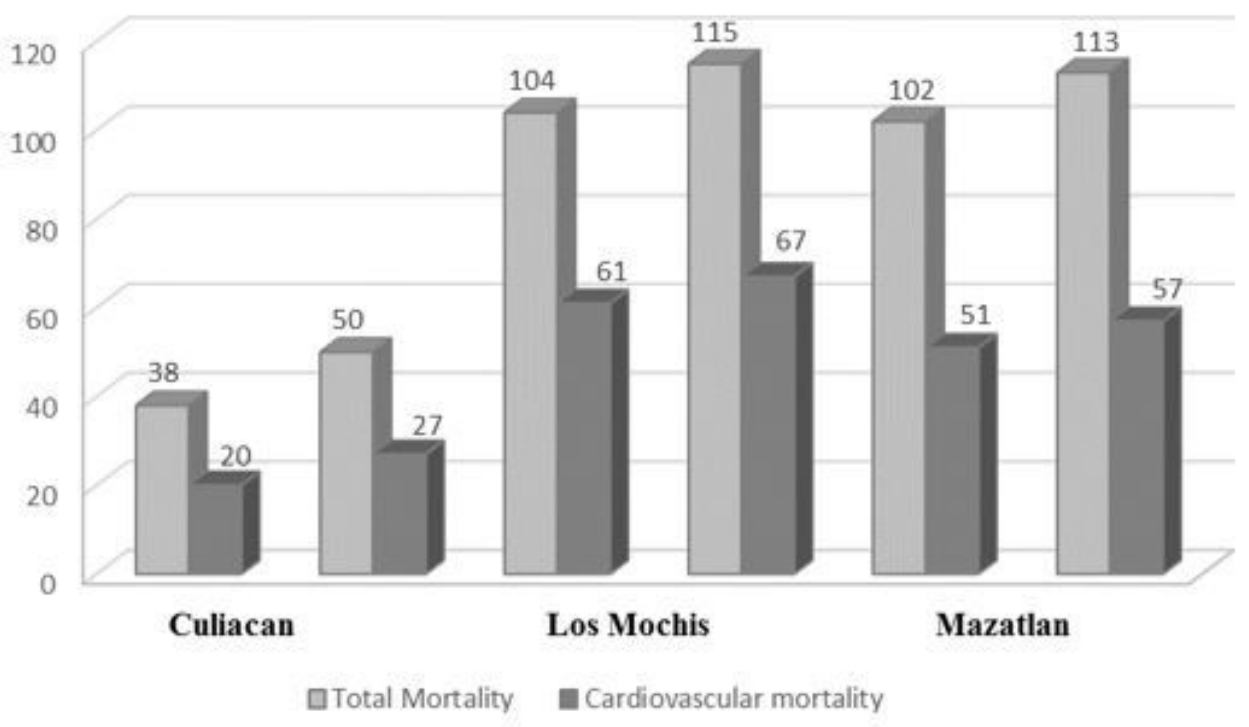

Figure 3

Avoidable total and cardiovascular mortality due to the reduction in PM2.5 concentration levels (a) (cases per 100,000 inhabitants) (b), for population older than 30 years in the three cities examined

\section{Supplementary Files}


This is a list of supplementary files associated with this preprint. Click to download.

- AppendixA.docx 